Psychology. Journal of the Higher School of Economics.

2021. Vol. 18. N 2. P. 364-378. DOI: 10.17323/1813-8918-2021-2-366-380

\title{
THE MOTIVATION OF DIFFERENTLY AGED VOLUNTEERS WHO HELP PEOPLE AND STRAY ANIMALS
}

\author{
A.E. VOROBIEVA ${ }^{\mathrm{a}}$, S.I. SKIPOR \\ ${ }^{a}$ Institute of Psychology, Russian Academy of Sciences, 13 build. 1, Yaroslavskaya Str., Moscow, 129366, \\ Russian Federation \\ ${ }^{b}$ Moscow University for the Humanities, 5 Yunosti Str., Moscow, 111395, Russian Federation
}

\begin{abstract}
Contemporary academic literature has controversial opinions about selflessness of motives of volunteers. Some authors state that volunteers are primarily motivated either by altruistic causes or egoistic factors; others declare the impossibility of the existence of pure altruists or egoists in the activity. Part of scholars report on the extreme importance of age regarding volunteers' motives. Conducted studies mostly consider volunteers with people. Papers investigating motives of volunteers with homeless animals are limited. A still unsolved question is whether it is reasonable to apply received results from those who volunteer with people to volunteers with non-human recipients. In the paper, we investigate the particularities and structures of motives among volunteers with diverse ages and recipients $(\mathrm{N}=220)$, utilizing VFI (Volunteer Function Inventory). The research sample consisted of volunteers serving people and/or homeless animals. It has been found that volunteers are mostly motivated by values, understanding, and enhancement functions. The social, career and protective functions were not common among the volunteers. Younger volunteers tend to be more multi-motivated and actuated by egoistic factors. Starting at age 25, the older the volunteer was, the more likely their motives were selfless and distinct. Studies such as ours can be valuable in recruitment and retention of volunteers according to their needs and motives. The obtained data can be used by organizations working with differently aged volunteers and diverse recipients of assistance (e.g., people, animals).
\end{abstract}

Keywords: volunteer, volunteering, motive, motivation, age, altruist, egoist, homeless animals.

\section{Introduction}

Many studies have been published on volunteer motives (e.g., Allison, Okun, \& Dutridge, 2002; Clary et al., 1998; Finkelstein, Penner, \& Brannick, 2005; Kudrinskaya, 2006; Kupreychenko, 2013). Motives for volunteering can be subdivided by researchers into truly altruistic or egoistic (Omoto \& Snyder, 1990). Volunteers with altruistic motives are those whose main goal in an activity is to help others and/or maintain their own well-being. Individuals with egoistic

The study has been executed as part of state assignment N 0138-2021-0010 "Socio-psychological factors of personality and group behavior in the context of global changes". 
motives volunteer because of a variety of self-interested reasons such as maintaining self-esteem, an opportunity to make new friends or to obtain new skills.

It was shown that volunteers are motivated by a desire to help others and improve the world around them and by their own initiative (Kudrinskaya, 2006); volunteers classified the opportunity to serve less fortunate people as important (Allison et al., 2002; Chapman \& Morley, 1999; Clary et al., 1998). Nonetheless, in some studies, the predominant motives were the possibility of self-realization, communicating with other volunteers, an opportunity to build and increase one's social capital or to obtain new skills (Azarova \& Yanitskiy, 2008). Some authors argued that there is no pure unselfishness in volunteerism as the activity tends to serve a variety of volunteer needs (Kuzminchuk \& Telepaeva, 2018).

It can be said that previous studies almost exclusively focused on volunteers who help people. A limited amount of research on motives of volunteers serving homeless animals has been conducted (Ferrari et al., 1999; Neumann, 2010; Nikolskaya et al., 2020; Prudkov \& Rodina, 2016; Zasloff \& Hart, 1998). There is evidence that volunteers of this type sincerely love and adore animals, and the activity provides them with an opportunity to take care of animals, and increase their self-esteem (Zasloff \& Hart, 1998). In addition, Prudkov and Rodina (2016) reported an extremely high level of altruism toward animals among volunteers, which was the predominant motive for them.

Interestingly, the literature review showed that according to the majority of definitions, the terms "volunteering" and "a volunteer" are related to serving people, not animals. Moreover, we presume that scholars might, by default, extrapolate study results from volunteers who help people onto other types of volunteers (e.g., environmental, wildlife, animal shelter volunteers).

One of the most commonly used approaches for studying volunteer motives is a functional one which states that each motive performs a specific function in volunteerism (Clary et al., 1998). Clary and colleagues specified the following motivational functions served by the volunteer activity:

1. Values. A volunteer has an opportunity to declare, express and maintain their own values related to altruistic, philanthropic, and humanitarian attitudes toward others due to this type of activity.

2. Understanding. This function provides a wide range of knowledge, experience and skills for volunteers and helps them to get the new, updated perspective on the world and themselves.

3. Social. It gives an opportunity to maintain and cultivate a relationship with the volunteer's peers. Volunteerism provides a chance to be encouraged by one's referent group, and this function is closely connected to social rewards and punishments.

4. Career. This function relates to obtaining career-relevant skills and knowledge. A volunteer activity can be viewed as a gateway into a career and the business world in general.

5. Protective. By volunteerism one can feel less lonely and less guilty for being more fortunate than others. Participating in the activity can provide a volunteer with a "shelter" for escaping one's bad feelings and problems. 
6. Enhancement. This function relates to an aspiration of personal growth and maintenance of one's self-esteem.

It can be said that only the motive of values relates to altruistic direction, whereas the others are considered as more egoistic (Kupreychenko, 2013).

The Volunteer Function Inventory (VFI) derived from the approach was developed by Clary and colleagues. The literature reports that values, understanding, and enhancement are the functions that appear to be the most observable and important volunteer motives (e.g., Allison et al., 2002; Clary et al., 1998; Planalp \& Trost, 2009).

In our paper we rely on this functional approach to volunteer motivation in consideration of the fact that there is no adapted VFI scale in Russia notwithstanding the popularity of this approach in our country. Russian authors have not yet achieved consensus regarding the most appropriate and valid questionnaire for studying volunteer motives (Sukharkova, 2017).

A series of studies indicate that age may be a factor in the primary motives. It was reported that younger volunteers more often than older volunteers rank typically "egoistic" functions (according to VFI) as significant (Finkelstein et al., 2005; Omoto et al., 2000; Pevnaya, 2015; Planalp \& Trost, 2009). Again, we are faced with the problem that the studies were conducted on a sample of volunteers with people.

One of the rare studies on the age characteristics of motives among volunteers with different recipients (Ferrari et al., 1999) showed that to some extent it is possible to project the results obtained on volunteers with people, onto volunteers with animals. It is worth noting that this study is not comprehensive or contemporary enough to provide us with sufficient data to form solid opinions about the relationship between age and motives of volunteers serving animals or people.

In general, we can conclude that the information on motives of volunteers with animals is insufficient. In fact, we know too little about this type of volunteering. At the same time, quite a lot of information has been accumulated about the motives and needs of volunteers with people.

A further question is whether it is reasonable to apply all findings to volunteers who help non-human recipients since obtained data is disproportional between these two types. On the one hand, volunteers who assist people personally, without recipient learning, are quite similar to volunteers who help animals because these two types of volunteers provide dependency help. The dependency type of volunteerism is considered as help without a skill transfer to the recipient (Maki \& Snyder, 2017). On the other hand, it is clear that volunteering with animals has its own features and particularities including the organization of activities and the community of such volunteers, the characteristics of the recipients (e.g., animals have many implicit needs) and the volunteers themselves - there is evidence that they are more introverted and less open to new experiences compared with volunteers with people (Nikolskaya et al., 2020). Thus, researchers cannot be certain whether the information obtained on motives from volunteers with one type of recipients is applicable to another one. 
Meanwhile, such specific data is extremely necessary for the accurate selection and retention of volunteers in various charitable organizations. There are many volunteer organizations, especially at educational institutions, where volunteers serve a variety of types of recipients: adults, children, stray animals, and so on. In such a situation, the validity and suitability of applying data obtained from one type of volunteers to others becomes crucial.

Therefore, the purpose of our empirical study was to study motives of volunteering on a diverse sample of volunteers (helping people and/or animals) and also to try to reproduce the data obtained on the age peculiarities of motivation in volunteers with people on a mixed sample of volunteers. Our hypothesis (1) was that younger volunteers are inclined to be actuated by egoistic motives in comparison with older volunteers.

Also, based on the reports that younger volunteers are more often motivated by career, social and other functions, it can be assumed that their motivational structure for volunteering is generally diverse. In addition, different age groups solve different problems at a certain period of life (Bromley, 1974). Thus, volunteering can become a platform for solving problems and issues that can be reflected in the difference in a structure of motivation among individuals of different ages. It is obvious that younger people face more issues in terms of personality which are new for them, and also have a wider range of needs, sometimes unconscious. Hence, our hypothesis (2) was that younger volunteers tend to be motivated by a more diverse set of motives in comparison with older volunteers.

\section{Method}

The sample of our research consisted of 220 volunteers from 16 to 64 years with an average age of 35 years. The sample of respondents included three types of volunteers: 1 . Those who helped homeless animals $(n=118), 2$. Those who served people interpersonally $(\mathrm{n}=79)$, and 3. Those who assisted both $(\mathrm{n}=23)$.

Survey data was collected from charity organizations all over Russia, including "Volunteers to HOrphans" (BF "Volontery - V Pomoshch Detyam-Sirotam"), the All-Russian Public Movement of Medical Volunteers ("Volontery - mediki"), the Charity Center for Psychological Rehabilitation of Seriously Ill Patients (OPORA), the Search and Rescue Squad "Lisa Alert" (Penza Region), the Charitable Foundation for Homeless Animals "Forest Shelter" ("Lesnoy priyut"), the Charitable Foundation for Homeless Animals "Kotodetki", and the Urban Animal Protection Fund.

The main data collection phase (early 2020) was preceded by a pilot study at a volunteer event in December 2019. Throughout personal conversations, we interviewed the volunteers in the pilot study in order to check if the questions in our forms are clear and comprehensible.

Participation in the main phase of the study was voluntary and anonymous. The respondents were offered an intangible reward at their will (a consultation based on the research results). Curators of volunteer organizations were also offered the processed summarized research results with recommendations for recruitment and 
training of volunteers. As additional motives for participating in the study, we noted the motives for helping science in investigating a socially important topic, as well as, separately for volunteers with animals, an opportunity for their social group to be made known, as it is poorly represented in scientific works. It is noteworthy that as we conducted our study, we received many reports from volunteers who assisted animals that they were happy that researchers were starting to pay attention to their community.

91.4\% of participants were women, and $8.6 \%$ were men, which represents the general population of Russian volunteers quite well (Kuzminchuk et al., 2018).

The requirements were the involvement in volunteer activities as frequent as at least several times a year, a cumulative volunteer experience of more than one year, and personal involvement (not only material aid, donations, etc.). $64.5 \%$ of our respondents participated in volunteer activities at least once a week, $23.2 \%$ no less than once a month, and $12.3 \%$ of volunteers served their recipients several times a year but less than once a month.

Additionally, the data was divided into four groups according to the Bromley's classification (Bromley, 1974): 1 - from 15 to 21 years $(\mathrm{n}=31), 2$ - from 21 to 25 years $(\mathrm{n}=14), 3-$ from 25 to 40 years $(\mathrm{n}=98), 4-$ from 40 to 65 years $(\mathrm{n}=77)$, with the unification of groups $40-55$ and 55-65 into one due to a small size of the group aged 55-65.

Thus, it can be said that our sample might be defined as representative, with some limitations related to specific particularities of the kind of volunteer activity (the type of served recipients).

To examine the volunteer motives, we asked our respondents to continue the phrase "I volunteer because of..." with an opportunity to choose preassigned answers (the quantity was unlimited). The following answers were created according to VFI (Clary et al., 1998):

I. I think that helping people is important. I feel sincere compassion toward those I assist. I suppose that it is necessary to help someone less fortunate than me.

II. Volunteerism helps me to know many new things, to learn something, and to obtain useful skills.

III. There are many volunteers among my friends. My close circle of friends encourages me to be a volunteer.

IV. The activity opens new career opportunities, increases my value on the job market, and expands my list of useful business contacts.

V. Volunteering distracts me from sad thoughts; it allows me not to think about my problems. I feel less lonely.

VI. Volunteerism maintains my self-respect and self-esteem. I am more self-satisfied, I feel important and necessary. The activity allows me to make new friends.

The Russian text of the form is presented in the Appendix.

In the original VFI, respondents assess 30 statements related to six functional motives on a 7-point scale from 1 (not at all important/accurate) to 7 (extremely important/accurate). Thus, for each motive, an average meaning is obtained, which is then compared with the rest. In our form, if the volunteers agreed with at least 
one statement within one category, they were asked to mark this motive as appropriate. The motives were assessed quantitatively for each respondent without ranking and assigning points.

\section{Results and Discussion}

Descriptive statistics were calculated for all variables used in the study using Excel.

The respondents in our sample $(\mathrm{N}=220)$ on average were motivated by 2.1 functional motives with minimum 1 and maximum 6 motives for each person. In total, 406 motives were marked for 220 respondents.

It is presented in Figure 1 that the number of motives is inversely proportional to age. As we can see, younger volunteers marked an average of 3.2 motives for each. On the other hand, older volunteers (40-65 years old) marked 1.7 functions as important on average.

As it is shown in Figure 2, 41.4\% of respondents were motivated by only one motive, $26.8 \%$ by 2 motives, and $18.6 \%$ by 3 . The multi-motivation with more than 4 motives was rare in the sample, less than 14\% altogether.

The Distribution of the Number of Motives per Volunteer among All Ages

Figure 1

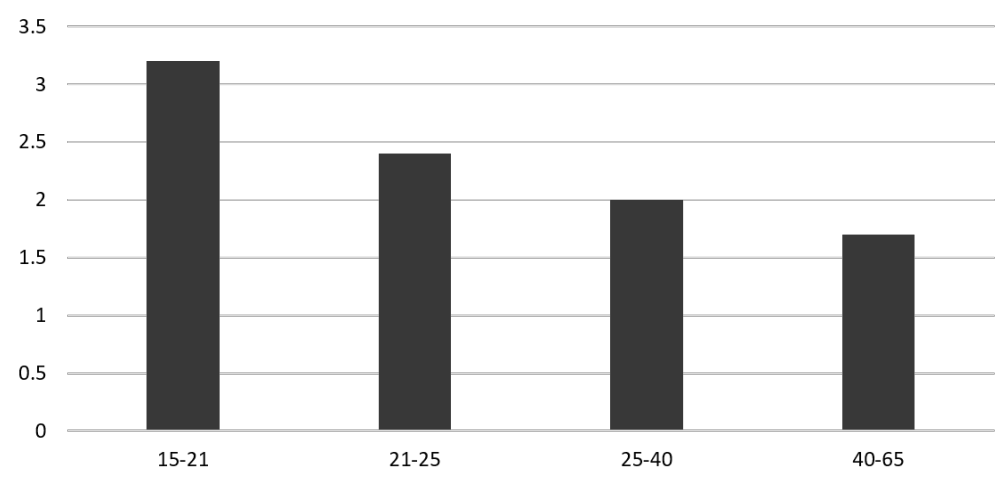

The Distribution of the Number of Motives among the Volunteers

Figure 2

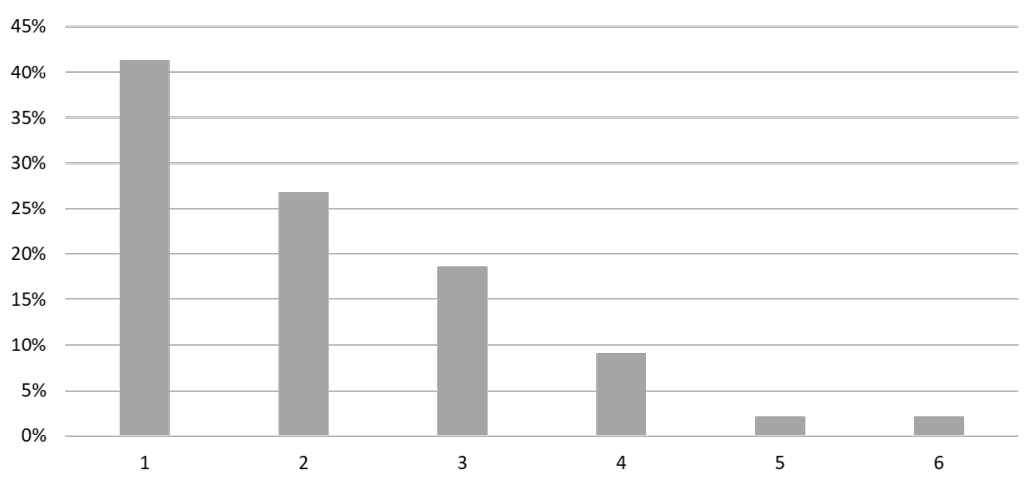


The mono-motivated volunteers $(\mathrm{n}=91)$ most often were motivated by the altruistic motive I $(82.4 \%, \mathrm{n}=75)$, less often by the enhancement motive VI $(14.3 \%, \mathrm{n}=13)$, and never by the protective one $-\mathrm{V}$; the remaining motives were represented in the responses at $1.1 \%$ each.

We found 31 combinations of the volunteers' motives $(n=129) .20 .2 \%(n=26)$ of respondents were simultaneously motivated by values (I) and understanding causes (II). For $13.2 \%(n=17)$ of respondents, volunteerism was an opportunity to express their own values (I) and maintain their self-esteem and self-respect (VI). 9.3\% $(\mathrm{n}=12)$ of volunteers pointed out that the activity is a good way to declare the importance to help others (I), obtain new skills and knowledge (II), and achieve personal growth (VI). 6.2\% $(\mathrm{n}=6)$ of participants were motivated by a combination of motives I, II, III, VI. The rest of the respondents' motives $(51.2 \%$, $\mathrm{n}=66$ ) were mixed and random.

According to Figure 3, among all detected motives, the most common were the altruistic motive I $(40.4 \%, \mathrm{n}=186)$, further motives II $(19.8 \%, \mathrm{n}=91)$ and VI $(19.6 \%, \mathrm{n}=90)$. Volunteerism for respondents was less likely to perform the functions of protection $(8 \%, \mathrm{n}=37)$, developing a career $(6.3 \%, \mathrm{n}=29)$, or social interaction $(5.9 \%, \mathrm{n}=27)$.

According to Table 1, volunteers aged 15-21 were more often motivated by the functions of humanistic values ( $29 \%$ of all motives), understanding (28\%) and personal growth (14\%). Respondents from 21 to 25 years old considered to be important the functions of understanding (28.6\%), career opportunities (22.9\%), as well as the ability to express their altruistic beliefs and support their self-esteem (20\% each). In fact, it was difficult to mark one leading motive among the group of young volunteers; however, functions I, II and VI were common for the group of young respondents.

It seems that starting from the age of 25 , the motivational structure of volunteers began to change toward a greater certainty and awareness of the reasons of activity. Respondents $25-40$ years old and $40-65$ were noticeably more often led by the altruistic motive I ( $40.7 \%$ and $51.6 \%$, respectively), with a significant margin considering maintenance self-esteem ( $21 \%$ and $19.5 \%$ ) and expansion of knowledge about the world (16.7\% and $15.6 \%)$ to be less important.

Figure 3

The Occurrence Frequency of Each Motive among the Volunteers

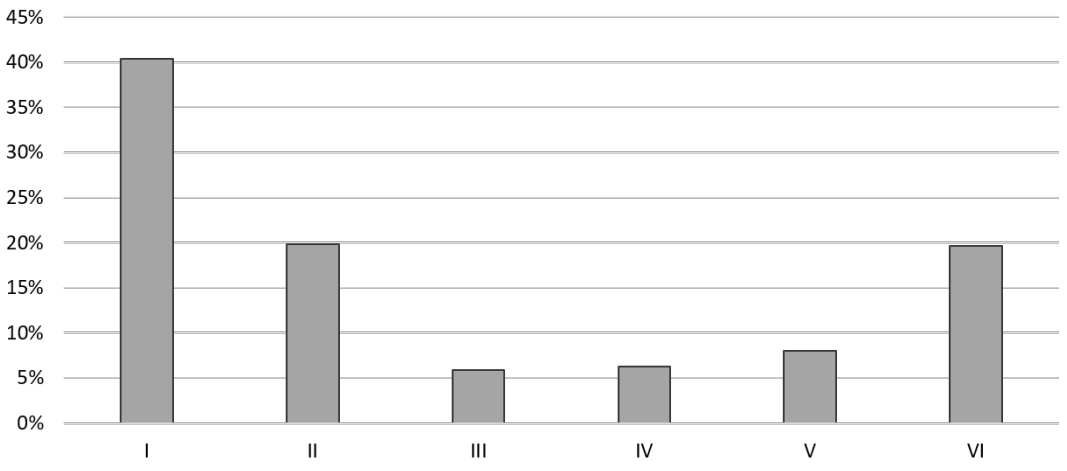


As it is shown in Figure 4, all motives, except for the defensive one (V) which was insignificant in all age groups, were unevenly represented in age groups.

For example, volunteers in the 21-25 age group less often marked the value function important (20\%) in comparison with respondents aged 15-21 (29\%), and also more often considered volunteering to be useful for their careers $(22.9 \%$ and $13 \%$, respectively). However, we would like to emphasize that the data obtained in the group of volunteers aged 21-25 requires rechecking in future studies due to the small size of the group in our study.

The vision of volunteering as an opportunity to learn something new seems to decrease with age (28\% of choices under the age of 21 and 15.6\% among those aged 40-65). It can be said that the need for personal growth through volunteering increased moderately with the age of the respondents (14\% among those aged 1521 and $19.5 \%$ at the age of $40-65$ ).

In order to test the hypothesis that younger volunteers tend to be motivated by more causes than older volunteers, we applied statistical analysis.

Table 1

The Number of Each Motive Among Volunteers of Different Age Groups

\begin{tabular}{|c|c|c|c|c|}
\hline \multirow{2}{*}{ Motives } & \multicolumn{4}{|c|}{ Age } \\
\cline { 2 - 5 } & $15-21$ & $21-25$ & $25-40$ & $40-65$ \\
\hline I & $27 / 29 \%$ & $7 / 20 \%$ & $83 / 40.7 \%$ & $66 / 51.6 \%$ \\
\hline II & $26 / 28 \%$ & $10 / 28.6 \%$ & $34 / 16.7 \%$ & $20 / 15.6 \%$ \\
\hline III & $6 / 6.4 \%$ & $1 / 2.9 \%$ & $22 / 10.8 \%$ & $6 / 4.7 \%$ \\
\hline IV & $12 / 12.9 \%$ & $8 / 22.9 \%$ & $5 / 2.5 \%$ & $3 / 2.3 \%$ \\
\hline V & $9 / 9.7 \%$ & $2 / 5.7 \%$ & $17 / 8.3 \%$ & $8 / 6.3 \%$ \\
\hline VI & $13 / 14 \%$ & $7 / 20 \%$ & $43 / 21 \%$ & $25 / 19.5 \%$ \\
\hline Total & $93 / 100 \%$ & $35 / 100 \%$ & $204 / 100 \%$ & $128 / 100 \%$ \\
\hline
\end{tabular}

Note. Raw data is presented first, the percentage values of observed data follow the slash.

Figure 4

The Distribution of the Number of Motives among the Volunteers

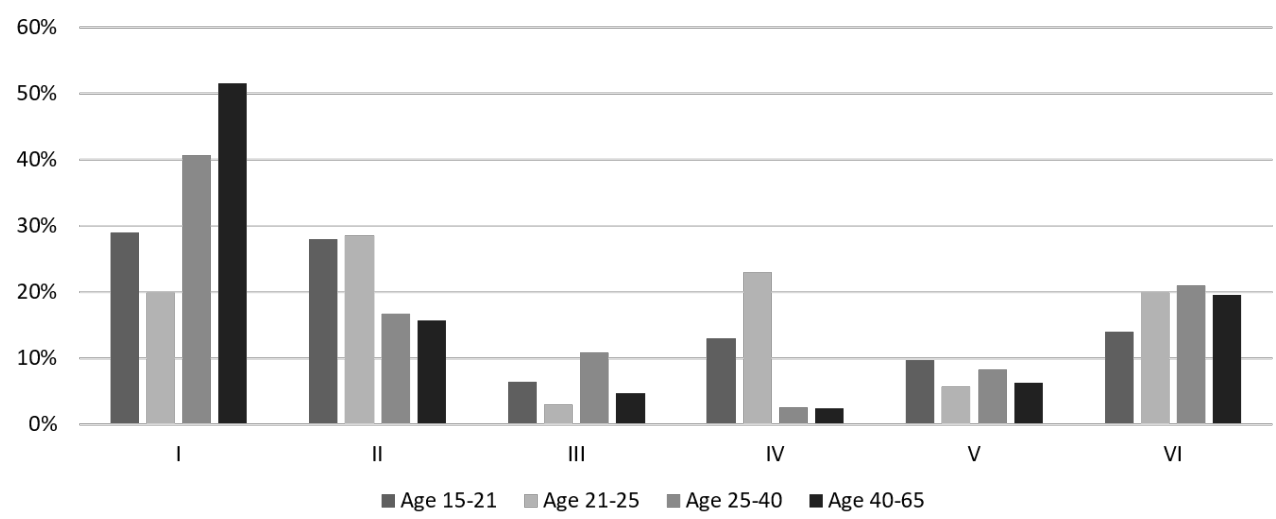


Statistical analysis was performed by using Spearman's rank correlation coefficient; data was normally distributed. We encoded respondents' ages as 1, 2, 3, 4, where 1 - respondents from 15 to 21 years, 2 - from 21 to 25 years, 3 - from 25 to 40 years, 4 - participants from 40 to 65 years. Motives were assigned as 1, 2, 3, 4, 5 , and 6 , where each number measured a quantity of motives per respondent. All statistics were calculated by using software IBM SPSS Statistics, version 22.

A highly significant inverse correlation was found between the number of motives and their age $(r(218)=-.37, p<.001)$. Thus, the younger volunteers were actuated by a wider variety of motives in contradistinction to the older volunteers who were motivated by fewer factors.

For testing the hypothesis that younger volunteers are inclined to be motivated by egoistic reasons while older volunteers are more often motivated by altruism, we marked motives II, III, IV, V, and VI as egoistic and I as altruistic. It was decided to consider the respondents who noted motive I as the only one as "altruists". The rest of the volunteers who indicated some other motives or a combination of various functions were defined as "egoists". For example, a volunteer with motives of values and understanding (I and II) was identified by us as belonging to the group of "egoists".

The data was tested by the Pearson chi-square $\left(\chi^{2}=15.407, \mathrm{df}=3, p<.01\right)$. As it is shown in Table 2, 87.1\% of respondents from 15 to 21 years were motivated by egoistic motives, $85.7 \%$ of the young volunteers (age 21-25) provided help because of the egoistic factors. On the contrary, $62.5 \%$ of respondents of age 55-65 were motivated by an altruistic motive. Each respondent was presented in cells of Table 2 only once.

At the next step, the Cramer's V was used to find out the strength of relationships among variables. It was revealed that there was a statistically significant correlation (Akoglu, 2018) between age and motives (Cramer's $\mathrm{V}=.265$ ).

Raw data is presented first, the sample expected values follow the slash, and the percentage values of observed data follow in parentheses.

The obtained data is concurrent to the past studies in terms of the prevalence of the motives of values, understanding and personal growth among volunteers (Allison et al., 2002; Clary et al., 1998; Planalp \& Trost, 2009).

Table 2

A Relationship between Age and Egoistic-Altruistic Mode of Motives among the Volunteers

\begin{tabular}{|c|c|c|c|c|}
\hline \multirow{2}{*}{ Motive } & \multicolumn{4}{|c|}{ Age } \\
\cline { 2 - 5 } & $15-21$ & $21-25$ & $25-40$ & $40-65$ \\
\hline Egoistic & $27 / 20.4(87.1 \%)$ & $12 / 9.2(85.7 \%)$ & $66 / 64.6(67.35 \%)$ & $40 / 50.8(51.95 \%)$ \\
\hline Altruistic & $4 / 10.6(12.9 \%)$ & $2 / 4.8(14.3 \%)$ & $32 / 33.4(32.65 \%)$ & $37 / 26.2(48.05 \%)$ \\
\hline Total & $31(100 \%)$ & $14(100 \%)$ & $98(100 \%)$ & $77(100 \%)$ \\
\hline
\end{tabular}

Note. Raw data is presented first, the sample expected values follow the slash, and the percentage values of observed data follow in parentheses. 
Also, we found that younger volunteers are more likely to be motivated by selfish reasons along with altruistic ones, and older volunteers tend to be more altruistic and mono-motivated. This correlates in part with previous research (Clary \& Snyder, 1999; Finkelstein et al., 2005; Omoto et al., 2000; Planalp \& Trost, 2009) and confirms findings that younger volunteers consider career and understanding functions to be more essential than older ones. However, in our study, the younger volunteers were not motivated by social function more often than the older respondents, as in the aforementioned works. Perhaps it stems from the lower development of the volunteer sector in Russia in comparison with the Western countries where the studies were conducted. For this reason, volunteers in Russia are unlikely to have other volunteers within their close circle of friends. Without close relationships with other volunteers, people are less motivated by incentive systems developed by charitable organization that are based on social relationships. Moreover, the fact that the majority of the respondents in our sample devote part or all of their volunteering time to helping non-human recipients may also have influenced the rarer choice of social function by volunteers. There is evidence that volunteers with homeless animals often work independently, they do not belong to any organization, and also quite rarely collaborate with other volunteers in general (Vorobieva \& Skipor, 2020). Therefore, social motivation for such volunteers does not play a big role, regardless of their ages.

Additionally, it was found that younger volunteers tend to rely on more motivating factors in their activities. Volunteers aged 15-25 did not single out a leading motive in their activities, marking it as an important opportunity to express their altruistic values, learn about the world, expand career horizons, and improve themselves. In other words, the motivational structure of young volunteers as a whole was characterized by equability and representation of all functions. This might occur due to their lack of extensive life experiences; such respondents were open to new things (exploring themselves and the world). Probably they had not yet established basic life and value orientations, and volunteering was a platform for their search and self-realization. It should be noted that volunteers at the age of 21-25 showed the maximum tendency toward a career motive among volunteers of other ages, which also correlates with certain life goals of people of this age. Moreover, volunteers in this age group were less likely to be motivated by value factors, in contrast to all other groups. The data obtained requires further verification, since in our sample this age group was small and cannot be fully representative.

It is worth noting that the self-report method we used to study the motivation of volunteers might have influenced the results obtained. Thus, respondents were more likely to give socially desirable answers during our survey, possibly with the goal of improving their self-presentation. For this reason, we considered as pure altruists only those respondents who marked a single value motive in their answers, without taking into account the respondents in this group who indicated mixed motives (the value one with some egoistic together, for example). In addition, the lack of a material reward could also lead to a bias in the results, since the study could have involved obviously less pragmatic and more selfless respondents from 
the outset. However, we hope that the anonymity of the respondents allowed them to be quite frank in their responses.

The present study allowed us to investigate once again the complex phenomenon of volunteer motivation on a diverse sample of volunteers in terms of recipients and also to clarify the structure and characteristics of the motives of volunteers of different ages. We hope that the results obtained can be useful, among other things, for mixed-type charities, where volunteers are involved in both serving people interpersonally and helping stray animals.

\section{Conclusion}

The first research on functional motives among a mixed sample of volunteers who help homeless animals and/or people among the Russian population has been conducted.

The volunteers overall were inclined to be mono-motivated. However, a substantial number of volunteers were actuated by several factors. Understanding the world and expressing altruistic values by means of volunteering became the most frequent conjunction of motives.

It was discovered that the volunteers were primarily motivated by an altruistic motive in general; social and career motives were ranked the lowest by the volunteers.

It was revealed that the younger volunteers were multi-motivated in the activity and more likely to meet a wide variety of their needs by volunteering.

Also, it was proved that the younger a volunteer is, the more they tend to be motivated by egoistic motives. In contrast, the older volunteers more often demonstrated an altruistic motive.

The limitations in our research are primarily associated with the uneven representation of various types of volunteers in the sample and the use of a self-report method. The questions formulated in Russian according to VFI require further consideration.

The results of our study are concurrent with some prior research in regard to the predominance of motives of values, understanding, and enhancement among volunteers. The presence of a correlation between age and motive was also confirmed on a mixed sample of volunteers working with different recipients.

Consequently, the results from the prior studies on the motives of volunteers serving people can be applied to volunteers who help homeless animals, with some limitations.

Future studies might be focused on investigating the structure of motives and how they are affected by volunteers' age, experience of volunteering, and different modes of the activity. 


\section{References}

Akoglu, H. (2018). User's guide to correlation coefficients. Turkish Journal of Emergency Medicine, 18(3), 91-93. https://doi.org/10.1016/j.tjem.2018.08.001

Allison, L. D., Okun, M. A., \& Dutridge, K. S. (2002). Assessing volunteer motives: a comparison of an open ended probe and Likert rating scales. Journal of Community and Applied Social Psychology, 12(4), 243-255. https://doi.org/10.1002/casp.677

Azarova, E. S., \& Yanitskiy, M. S. (2008). Psychological determinants of volunteer's activity. Tomsk State University Journal, 306, 120-125. (in Russian)

Bromley, D. B. (1974). The psychology of human ageing (2nd ed.). Penguin Books.

Chapman, J. G., \& Morley, R. (1999). Collegiate service-learning: Motives underlying volunteerism and satisfaction with volunteer service. Journal of Prevention and Intervention in the Community, 18(1-2), 19-33. https://doi.org/10.1300/J005v18n01_03

Clary, E. G., \& Snyder, M. (1999). The motivations to volunteer: Theoretical and practical considerations. Current Directions in Psychological Science, 8(5), 156-159. https://doi.org/10.1111/1467-8721.00037

Clary, E. G., Snyder, M., Ridge, R. D., Copeland, J., Stukas, A. A., Haugen, J., \& Miene, P. (1998). Understanding and assessing the motivations of volunteers: A functional approach. Journal of Personality and Social Psychology, 74(6), 1516-1530. https://doi.org/10.1037/00223514.74.6.1516

Ferrari, J. R., Loftus, M. M., \& Pesek, J. (1999). Young and older caregivers at homeless animal and human shelters: Selfish and selfless motives in helping others. Journal of Social Distress and the Homeless, 8(1), 37-49.

Finkelstein, M. A., Penner, L. A., \& Brannick, M. T. (2005). Motive, role identity, and prosocial personality as predictors of volunteer activity. Social Behavior and Personality: An International Journal, 33(4), 403-418. https://doi.org/10.2224/sbp.2005.33.4.403

Kudrinskaya, L. A. (2006). Dobrovol'cheskii trud: sushchnost', funktsii, spetsifika [Volunteer labor: essence, functions, specificity]. Sociological Research, 5, 15-22.

Kupreychenko, A. B. (2013). Problema izucheniya motivov i psikhologicheskikh bar'erov volonterskoi aktivnosti molodezhi [The problem of studying the motives and psychological barriers of youth volunteer activity]. In A. V. Kaptsov (Ed.), Professional'noe i lichnostnoe samoopredelenie molodezhi v sovremennoi Rossii [Professional and personal self-determination of youth in modern Russia] (pp. 143-150). Samara: SamLuxPrint.

Kuzminchuk, A. A., Pevnaya, M. V., \& Timirshina, E. R. (2018). Types of youth voluntaring: specificity and prospects of development. Surgut State Pedagogical University Bulletin, 2(53), 68-77. (in Russian)

Kuzminchuk, A. A., \& Telepaeva, D. F. (2018). Molodye volontery: al'truisty ili egoisty? [Young volunteers: Altruists or egoists?]. In Yu. R. Vishnevskii (Ed.), XXI Ural'skie sotsiologicheskie chteniya. Sotsial'noe prostranstvo i vremya regiona: problemy ustoichivogo razvitiya [XXI Ural Sociological Reading "Social Space and Time of the Region: Problems of Sustainable Development"] (Vol. 21, pp. 424-429). Ekaterinbur: Gumanitarnyi universitet. (in Russian)

Maki, A., \& Snyder, M. (2017). Investigating similarities and differences between volunteer behaviors: Development of a volunteer interest typology. Nonprofit and Voluntary Sector Quarterly, 46(1), 528. https://doi.org/10.1177/0899764015619703

Neumann, S. L. (2010). Animal welfare volunteers: who are they and why do they do what they do? Anthrozous, 23(4), 351-364. https://doi.org/10.2752/175303710X12750451259372 
Nikolskaya, A. V., Kostrigin, A. A., \& Thurmer, A. (2020). A comparative analysis of the personality traits and motivations for activities on the part of volunteers helping people and those assisting homeless animals. Journal of Human Behavior in the Social Environment, 30(6), 667-679. https://doi.org/10.1080/10911359.2019.1647482

Omoto, A. M., \& Snyder, M. (1990). Basic research in action: Volunteerism and society's response to AIDS. Personality and Social Psychology Bulletin, 16(1), 152-165.

https://doi.org/10.1177/0146167290161011

Omoto, A. M., Snyder, M., \& Martino, S. C. (2000). Volunteerism and the life course: Investigating age-related agendas for action. Basic and Applied Social Psychology, 22(3), 181-197. https://doi.org/10.1207/S15324834BASP2203_6

Pevnaya, M. V. (2015). Studencheskoe volonterstvo: osobennosti deyatel'nosti i motivatsii [Student volunteering: Motivation of volunteers and specific features of their activity]. Vysshee Obrazovanie v Rossii, 6, 81-88. (in Russian)

Planalp, S., \& Trost, M. (2009). Motivations of hospice volunteers. American Journal of Hospice and Palliative Medicine, 26(3), 188-192. https://doi.org/10.1177/1049909108330030

Prudkov, P. N., \& Rodina, O. N. (2016). On altruism toward nonhuman animals. Society and Animals, 24(4), 321-336. https://doi.org/10.1163/15685306-12341419

Sukharkova, M. P. (2017). Approaches to studying motivation to participate in volunteer practices. Theory and Practice of Social Development, 9, 12-16. https://doi.org/10.24158/tipor.2017.9.2 (in Russian)

Vorobieva, A. E., \& Skipor, S. I. (2020). Comparative analysis of characteristics of the activities of volunteers with nonhuman animals and volunteers helping people. Chelovecheskii Kapital [Human Capital], 9(141), 253-263. https://doi.org/10.25629/HC.2020.09.23 (in Russian)

Zasloff, L. R., \& Hart, L. A. (1998). Attitudes and care practices of cat caretakers in Hawaii. Anthrozoos: A Multidisciplinary Journal of the Interactions of People and Animals, 11(4), 242-248. https://doi.org/10.2752/089279398787000599

Anastasia E. Vorobieva - Senior Researcher, the Laboratory of Social and Economic Psychology, Institute of Psychology, Russian Academy of Sciences, PhD in Psychology.

Research Area: social psychology, moral psychology, economic psychology, advertising psychology, psychology of leisure.

E-mail: aeVorobieva@yandex.ru

Sofiia I. Skipor - BSc, Department of Psychology, Moscow University for the Humanities.

Research Area: social psychology, prosocial behavior, volunteering.

E-mail: skipor.sofia@gmail.com 


\title{
Мотивация волонтеров разного возраста, помогающих людям и бездомным животным
}

\author{
А.Е. Воробьева ${ }^{\mathrm{a}}$ С.И. Скипор \\ ${ }^{a}$ ФГБУН «Институт психологии РАН», 129366, Москва, ул. Ярославская, д. 13, к. 1 \\ ${ }^{b}$ АНО ВО Московский гуманитарный университет, 111395, Москва, ул. Юности, 2.5
}

\section{Резюме}

Современная академическая литература характеризуется противоречивостью относительно бескорыстности мотивов волонтеров. Некоторые авторы утверждают, что волонтеры мотивированы преимущественно или альтруистическими, или эгоистическими причинами; другие заявляют, что существование чистых «альтруистов» и «эгоистов» в принципе невозможно в подобной деятельности. Часть исследователей сообщают о критической важности возраста волонтера, когда речь заходит о его мотивах. Большинство проведенных исследований рассматривали волонтеров, которые помогают людям. Работ, изучающих мотивы волонтеров, которые помогают бездомным животным, крайне мало. Нерешенным вопросом остается, обоснованно ли применять результаты, полученные на волонтерах, помогающих людям, к волонтерам, помогающим животным. В данной работе мы исследуем особенности и структуру мотивов среди волонтеров разных возрастов $(\mathrm{N}=220)$, используя VFI (Volunteer Function Inventory). Выборку исследования составили волонтеры, помогающие людям и/или бездомным животным. Было обнаружено, что волонтеры по большей части мотивированы функциями ценностей, понимания и личностного роста. Социальный, карьерный и защитный мотивы не были характерны для добровольцев. Молодые волонтеры, как правило, более мульти-мотивированы и чаще движимы эгоистическими факторами. Начиная с 25 лет, чем старше был волонтер, тем более вероятно его мотивы были бескорыстными и четко определенными. Исследования, подобные нашему, могут быть полезными в наборе и удержании волонтеров, исходя из их потребностей и мотивов. Полученные данные могут быть использованы организациями, работающими с волонтерами разных возрастов и с различными реципиентами помощи (например, с людьми, животными).

Ключевые слова: волонтер, волонтерство, мотив, мотивация, возраст, альтруист, эгоист, бездомные животные.

Воробьева Анастасия Евгеньевна - старший научный сотрудник лаборатории социальной и экономической психологии, ФГБУН Институт психологии РАН, кандидат психологических наук.

Сфера научных интересов: социальная психология, психология нравственности, экономическая психология, психология рекламы, психология досуга.

Контакты: aeVorobieva@yandex.ru

Скипор София Ильинична - бакалавр, факультет психологии, Московский гуманитарный университет.

Сфера научных интересов: социальная психология, просоциальное поведение, волонтерство. Контакты: skipor.sofia@gmail.com 


\section{The Form to Study the Motives of Respondents (Based on VFI)}

Appendix

Я занимаюсь волонтерской деятельностью потому, что... (можно выбрать несколько вариантов):

Я думаю, что помогать другим - это очень важно. Я искренне сострадаю тем, кому помогаю. Считаю, что нужно помогать тому, кому повезло меньше, чем мне;

Волонтерская деятельность позволяет узнать много нового, научиться чемуто, приобрести полезные навыки;

Среди моих друзей много волонтеров. Мое близкое окружение поощряет мои занятия волонтерской деятельностью;

Волонтерская деятельность открывает новые карьерные возможности, повышает мою ценность на рынке труда, позволяет мне расширить круг полезных деловых контактов;

Это отвлекает меня от грустных мыслей, позволяет не думать о собственных проблемах. Я чувствую себя менее одиноким;

Подобная деятельность поддерживает мое самоуважение и самооценку, я более доволен собой, чувствую себя нужным и важным. Волонтерская деятельность позволяет мне заводить новых друзей. 